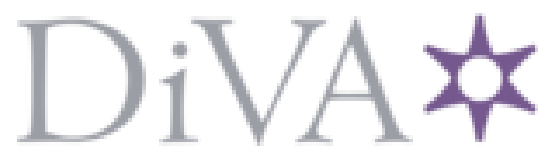

http://www.diva-portal.org

This is the published version of a paper published in Designs for Learning.

Citation for the original published paper (version of record):

Smeds, K. (2012)

On the Meaning of Exhibitions: Exhibition èpistèmes in a historical perspective.

Designs for Learning, 5(1-2): 50-72

http://dx.doi.org/10.2478/dfl-2014-0004

Access to the published version may require subscription.

N.B. When citing this work, cite the original published paper.

Permanent link to this version:

http://urn.kb.se/resolve?urn=urn:nbn:se:umu:diva-111605 


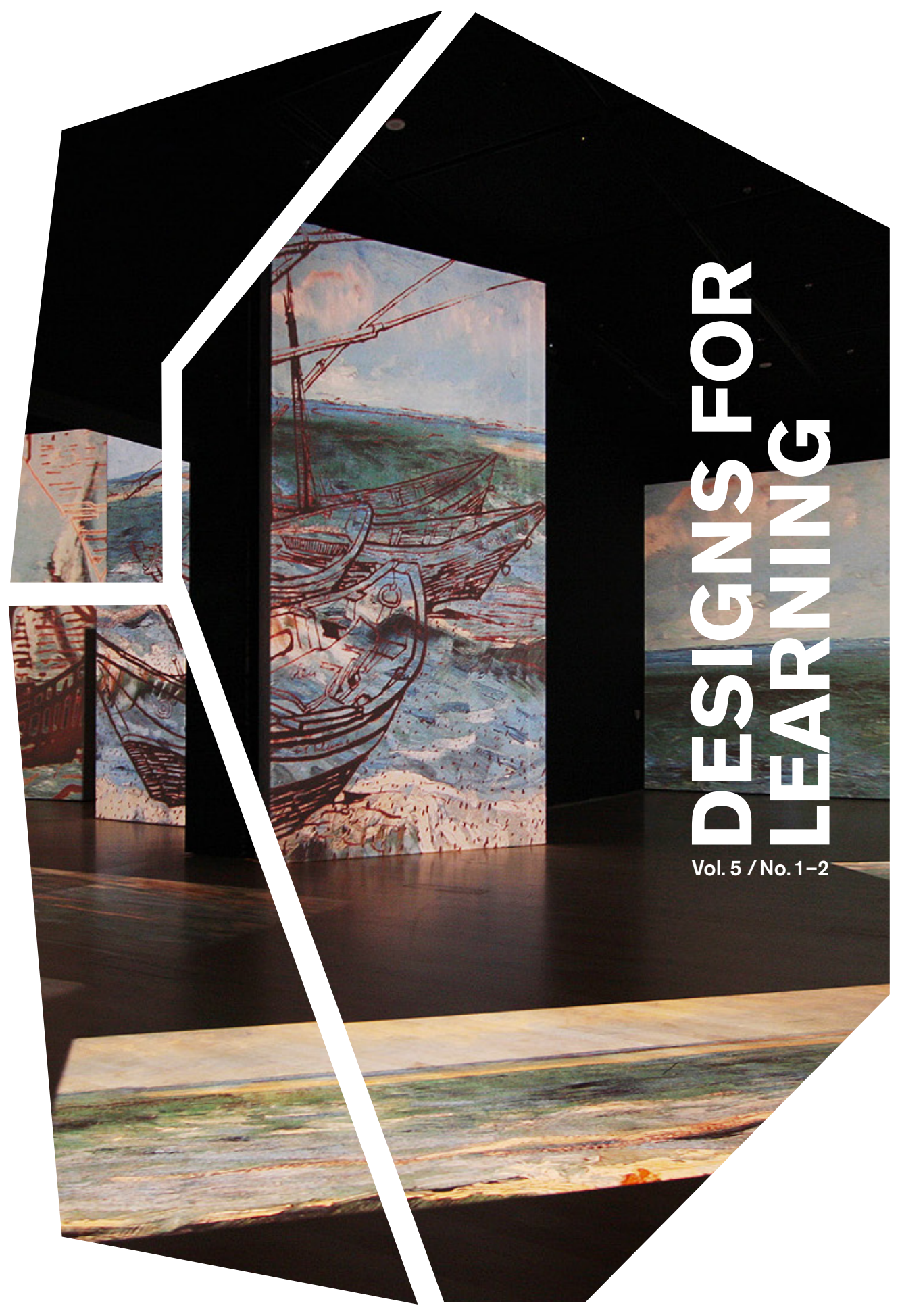

Designs for Learning

Volume 5 / Number 1-2 


\title{
On the Meaning of Exhibitions - Exhibition Epistèmes in a Historical Perspective
}

\author{
By KERSTIN SMEDS, University of Umeå, Sweden
}

This essay aims at contributing to our understanding of the nature of exhibitions, namely how and why we make them, and what they - and the things in them - might symbolize. My focus will be on exhibitions of objects in classical museums of cultural history, archaeology and ethnology/ethnography. I will discuss how scientific epistemologies and discourses, as well as the history of ideas and ideologies, are reflected in the way museums and exhibitions are organized. Theoretically, I will lean on ideas of Michel Foucault presented in his work The Order of Things (Foucault, 1991) and Power/Knowledge (Gordon 1980), but also on Mieke Bal's Double Exposures (1996), and a few others.

THINGS BEING NAMED AND ORDERED

What "is" an exhibition? An exhibition could be defined as a spatially organised and visualised expression of thoughts, things and systems of knowledge, originating in the time of Enlightenment, and to a great extent based on the display of material objects. If, then, you ask people what the Enlightenment was all about, the answer would prehaps be: a cultural manifestation of rational thinking, scientific accuracy, observation and experiment, followed by classification in order to build universal sytems of knowledge. Diderot's Encyclopaedia would be given as a good example of this striving for universality.

But rational systems, experiment and a striving for universality was nothing new - already Aristotle had this urge. Medieval and Renaissance thinkers had also been busy building universal systems, in their efforts to cast light on the order of Cosmos; to explain the Universe created by God. In 
this Universe every single "thing", every phenomenon - be it material or immaterial - had its given place. Science - and scientists - had "only" to discover it all, reveal things and lay them bare. Discovery gained control over the discovered. Objects from newly discovered parts of the world where brought together as representations of the wonders created by God. In the Age of discoveries, objects were gathered and shown in collections of naturalia and artificicalia in the Cabinets of Curiosities or the 'Kunstkammern' of the time (Wagner 1994, p. 24). By showing and studying the material, you could - so they thought - also learn about its origins and contexts. This was the core idea with collections.

This early development of museums was intimately associated with the development of the sciences and the arts, since many of the sixteenth and seventeenth century cabinets of Naturalia, Artificialia and Curiosities were assembled by scholars linked to libraries and universities and were used for research and educational purposes. These early cabinets and museums that is: exhibitions - were usually arranged according to rational, "prescientific" systems of comparison and resemblance: convenientia, analogia, sympathia, imitatio and aemulatio (Foucault 1991, p. 18-26). Thus objects which had the same colour or just resembled one another in form, were put together in a classification system - and consequently also in the display. At the end of the 17th century a collection on display was at times called An Allegory of the Sense of Sight.

However, all these classificatory systems - even with Carl von Linné at the 18th century - were based on the firm belief that our world was created and ruled by God. Man's efforts of exploring, understanding and ordering were only due to "revealing" it all. Beginning with the early Modern era in the 17th century, science was a world of observation and experimentation. It was based on "a system of looks", based on the Cartesian principle of a subject - the observer - being separated from the object - the observed - that is, from nature and the material world. That which was observed, "objectively" and "neutrally", had then to be named, otherwise it could not be interpreted, nor controlled, nor classified or communicated.

The separation between 'subject' and 'object' encompassed the problem of objectivity, of seeing and naming. What came first: the thing in itself, or the knowledge/idea of it? One of the philosophical conclutions was that the "thing" (object) doesn't actually exist without its name; the object, with all 
its connotations to human life, was "born" only at the very moment we gave it a name and interpreted it's function. Another result of this process was that the physical "world" around us became separated from "us". Nature, or the "world", was going on out there, and reachable/understandable for us only by naming it in our language, with the aid of which it would be represented. The theory of analogies, resemblances and sympathies between things was gradually replaced by the theory of serial structures and temporal arrangements and hierarchies - that is: taxonomy (Foucault 1991, p. 53f). As soon as Man, the "observer", was sure he could manipulate, exploit and control Nature, the latter became subordinate and dependent on Man's rational reasoning.

The relationship (or gap) between thought/idea and matter, and the "names", systems and models of representation that were found out to bridge this gap, would be considered one of modern philosophy's pivotal problems (Lyotard 2003, p. 159).

Representation and classification became the tools with which to gain control over the world around us and to bridge this gap between 'thing' and 'word'.To classify is to build systems, to structure the visible in linguistic terms, to sort the unknown into the map of knowledge and control. According to Foucault, the "space" between an object and its name is the "room of representation" which we fill with meaning, symbols and linguistic structures (Foucault 1991, p. 130). At the end of the 18th century, the march of the Object through human Time and Space started (e.g. within History and Archaeology), and objects were used as evidence of national and cultural roots in the system of scientific knowledge.

Representation is thus dwelling somewhere in "space" between the scientific observation and the describing and explaining presentation or visualization - which, for instance, takes place in museum exhibitions. Foucault's "room of representation" was inhabited by the human idea of a 'thing' and the idea of another 'thing', linked together only by signifyers, signs, symbols and metaphors (Foucault 1991, p. 128). This structuring of knowledge that which could be measured and "seen" in linguistic, universally accepted terms - eventually replaced the mechanistic world view.

The field of classification was a field of conflict. Many competing theories as to how to organize the world occurred - and for a long time there was no concensus about what should be included and what excluded from 
these taxonomies. Classification, even for Linné, was (and is) a means of exlusion, not only inclusion. That which was left out, or which itself resisted an integration or was impossible to fit into the system, drifted as a kind of rationality's leftovers on the backyards of civilisation. The importance of museum collections for Western civilisation and culture lay in the power of hiding away and forgetting, as much as in selecting and including. Out of that emerged another problem, still persisting in the world of exhibitions: pars-pro-toto, the fact that every object in a museum collection is only a part of a whole, only representing the whole, and will therefore easily be loaded with more information about social, cultural and exconomic reality than the object, so to say, in itself would ever reveal (Fehr 1988, p. 110). Thus early museums and exhibitions were exclusive not only due to their hidden scientific codes, but also due to the pars-pro-toto character of collections.

EXHIBITION AS AN EPISTEMOLOGICAL DISCURSIVE ACT

How did museum exhibitions develop in this context? It seems that museums and exhibitions were a more or less inevitable result of the process described. According to Foucault, one of the solutions of the philosophical and existential conflict between subject and object, was to let those "maps" of knowledge one had built up as linguistic and taxonomic structures, be turned, "embodied" into physical patterns and a spatial form. He notes that the inevitable institutional implication of all this taxonomy and systembuilding was indeed museums (e.g. of natural history) and botanic gardens (Foucault 1991, p. 64). The immaterial taxonomic system was concretized by being "laid out" neatly and properly in a three dimensional space: the museum. Otherwise these objectified knowledge systems wouldn't be observable by other studiosi, and studied and communicated to students. Thus an exhibition, a public demonstration of things, is originally an epistemological practice born out of taxonomy and science.

When something is made public in an exposition, it involves bringing out the deepest held views and beliefs of a subject, says Mieke Bal. This subject - which by Bal is called expository agency - exposes itself in an exhibition as much as does the object. That, the posture or gesture of exposing, is a particular form of discursive behavior (Bal 1996, p. 2).

We are putting out - ex positioning - objects in space according to systems or maps of thought, interpretation and meaning. A coup de représen- 
tation shifts the meaning of objects from one position: everyday life and reality - to another: the museum exhibition. The expository "agency" is not to be understood as a real person, it is not to be mixed with individual intention, for instance of the curator planning the exhibition. "Expository agency" is rather tied up to social and cultural and scientific power structures within in the museum in question; the "agency" is the subject of "semiotic behavior in which the constative use of signs prevails" (Bal 1996, p. 8). The "expository agency" is always there, be it visible and apparent for the visitor/recipient or not. It is kind of inscribed in the presentation. For Bal, the "expository agency" points at things, collects them, gives them names, put them on display and says: look, that's how it is! Thus, an exhibition is always a "constative act" [to indicate something as factual], which embraces the authority of the "agency" who knows things. This would be called an epistemic authority (Bal 1996, p. 2f).

Furthermore, an exhibition is always also an argument, some even call it an "act of speech" - be written text involved in it or not. The discursive act of the "expository agency" uses things (objects) as signs for producing arguments and meaning according to a system and practice of display that "it" finds appropriate - according to the prevailing episteme. Mieke Bal defines, in this context, a discourse as a "set of semiotic and epistemological habits that enables and prescribes ways of communicating and thinking that others who participate in the discourse can also use" (Bal 1996, p. 3). An exhibition, then, would according to Bal be seen as a discursive praxis.

In fact, Bal's concepts of discourse and agency would, speaking with Foucault, be equivalent with the concept of episteme which I would prefer to use here. For my purposes, I also find episteme a more useful concept than for instance the all embracing scientific paradigm by Thomas Kuhn. Firstly, an episteme might consist of several discourses (as do an exhibition). Secondly, Foucault defined an episteme merely as a "strategic apparatus" in the "field of scientificity" rather than a tool with which one could separate false from truth (Foucault 1980, p. 197).

Foucault's episteme is not merely confined to science but to a wider range of discourse (all of science itself would fall under the episteme of the epoch). While Kuhn's paradigm shifts are a consequence of a series of conscious decisions made by scientists to pursue a neglected set of questions, 
Foucault's epistemes are something like the 'epistemological unconscious' of an era; the configuration of knowledge in a particular episteme is based on a set of fundamental assumptions that are so basic to that episteme so as to be invisible to people operating within it.

Foucault made it clear that several epistemes may co-exist and interact at the same time, being parts of various power-knowledge systems. These definitions are exactly applicable to the points I want to make when trying to sort out an epistemology of exhibitions below. Particularly appropriate is Foucault's statement of episteme as "epistemological unconscious of an era".

Furthermore, speaking about what an exhibition "is", it is important to note that a modern exhibition is not an outline of only one, but several discourses. And the "discursive praxis" would comprise a wide range of means and discourses, though all coming under the prevailing episteme.

According to the Austrian museologists Roswitha Muttenthaler and Regina Wonisch, a modern exhibition would be characterized as a "hybride medium". This comprises several forms of visualization and presentation: objects, images, film, text, as well as exhibition architecture, light, color and design are contextualized in a certain space and are woven into a thick "texture" (in einer dichten Textur verwoben) (Muttenthaler /Wonisch 2006, p. 37). Every displayed object is juxtapositioned in a special relation to other objects, to texts and images and other elements of the exhibition. These interrelationships allows the objects and other elements to form a general "expression" of the exhibition. Bal, in her turn, would involve this expression as part of the "narration" of the exhibition - the "story" told.

The idea of a "hybrid medium" again, could (I think) be considered equivalent with what Gunther Kress and Theo van Leeuwen would call a "multimodal ensemble" - though there is an important distinction. The former don't bother to go any deeper into the problem of "hybrid" and what consequences this diversity has for meaning-making, while the concept of "multimodality" would make the whole difference as for how meaning-making occurs (happens). An exhibition wouldn't by Kress/Leeuwen be called only an "act of speech" or a statement or utterance of some hidden (or visible) museal epistemological practice and discourse, but a display of many diverse discourses forming one integrated multimodal "text" (Kress 
\& van Leeuwen, 2001). This "text" is communicating something as soon as the visitor appears and starts "reading" / 'engaging with' it, thus creating (designing) meaning, or inother words "learning".

\section{A “TABleau” of EXHibition EPISTEMES}

In this "tableau" (see Fig. 1) I am presenting a proposal of exhibition epistemes that I will discuss in more detail. The terms used within each column of the tableau are meant only as key words of predominant discourses and exhibitionary "agencies" in each. The development of the exhibition medium that I present here is often described in linear terms of an evolutionary process along with the historical development, and from the more closed, exclusive and one dimensional exhibition to the ever more complex and open medium of today. But the process is hardly ever linear, and further, by no means simultaneous in museums in different parts of the world. Within this frame, I suggest that my "tableau" presents kind of generalizing overview.

\section{Episteme I \\ Enlightenment (closed) \\ ca 1750 and on

Taxonomy
Typology
"Objectivity"
Truth/Authority
Non-textual
Exclusive
Aesthetic
Universality
One dimensional
Chronology
Progress
Linear
Evolution (ca 1860 on)
"One way"

TAXONOMY

POSITIVISM

DARWINISM

Episteme II Enlightenment
prevails (more open)
ca1860 on
Text!
History
Nation/Narration
Truth/Authority
Normative
Inclusive/integrative
Homogeneity
Education
Consensus
Collectivism
Universality
Chronology
Progress
Linear
Evolution

POSITIVISM

DARWINISM

\author{
Episteme III \\ Enlightenment out? (open) \\ late 1980's - \\ "Folksonomy" \\ Text(s) \\ Thematic \\ Storytelling \\ Polyvocal / Dialogue \\ Multi-dimensional \\ Interpretive \\ Message(s) \\ "Auteur" \\ Experience \\ Individualism \\ Diversity \\ Reflexivity \\ "Game" \\ Network \\ Nonuniversal \\ Nonevolutionary \\ Nonlinear \\ "Path Finder" \\ HERMENEUTICS \\ STRUCTURALISM \\ POSTSTRUCTURALISM
}


This "Tableau" indeed looks very neat and tidy: everything clearly tucked in the blocks where it belongs. Historically, I have chosen to divide the development into three phases/epistemes. But these epistemes are, as I tried to explain above, by no means in any way rigid entities; on the contrary, there is considerable overlapping between them. Referring back to Foucault, several epistemes may co-exist and interact at the same time. Beginning in the mid-18th century, loosely in agrement with historical epochs, it is important to keep in mind that a new episteme was only added to the other in the long run of epistemological development, and that the years mentioned would only indicate an approximative starting point. Eventually (today) all epistemes exist simultaneously, sometimes even in one and the same museum. But trends and changes are, as I will argue, still moving in the direction from episteme I to III.

The introduction of Episteme I occured around 1750 with the shaping of modern museums (e.g. the British Museum), following the dissolution of the curiosity cabinets, and with small epistemological shifts along the way. After 1860 the theory of evolution was introudced, which has never left the museums. Episteme II then, was based on the disintegration of l'ancien règime, along with nationalism and the development of the modern nation state; and the emergence of 'parlamentalism' and democracy. This episteme was initiated around the mid-nineteenth century, reached its heyday in the 1920s, progressed into a 'mature' state after the Second World War and prevails till this day.

Episteme III would eventually be defined as an entirely new, modern episteme of poststructural networking and, interpreting Foucalt, more lika a "strategic apparatus", which started to be implemented in museums in the late 1980’s.

EPISTEME I: TAXONOMY, TYPOLOGY AND TRUTH

An exhibition, based on the principles of the Enlightenment, was a visualization and embodiment of scientific systems of classification in a threedimensional space. Taxonomy was simply turned into 'body', into a spatial and material "landscape" of glass cases filled with typologically arranged items. The first modern museums in Europe were organized according to taxonomical principles striving for universality. In its early stages, the British Museum (1753, opened 1758) was designated 'the Universal Museum', faithful to the emerging imperialism of Great Britain (Lord 2004; Sloan \& 
Burnett 2003, p. 77, 91). The British Museum soon adopted the Linnaean system of classification, which would become predominant in museums across Europe (Huxley 2003:, p. 77, 91).

In many museums of today, especially specialized museums such as coin cabinets, the Episteme I still prevails. The leading principle in Episteme I is, as we have seen, a taxonomy based on scientific observation, interpretation and documentation, aimed at portraying the objective 'truth' about 'things' and about reality (e.g. in the past). They were (and are) exclusive, physically as well as intellectually/didactically, in other words not open for or accessible to everybody. If anyone, at this time, had spoken of target groups, this would have been an elite of "studiosi". Exhibitions of this kind offer scarce or no information about the origin and previous ownership of objects, nor about their social or other contexts. Also, the means of display would be characterized as "aestheticism", which means that objects are treated as unique objects of Art, stripped of all contexts and contents. Episteme I exhibitions ignore "common" visitors' needs and expectations. There is a presupposition that the audience consists of educated people. The "expository agency" is not revealed nor recognized, in contrast to exhibitions of Episteme III, where the curator, producer or the "auteur", representing the "agency", would be signing the exhibition as a more or less personal product.

The value and meaning of an exhibition of Episteme I is kind of inherent; a factual "utterance" of epistemic authority. Encyclopaedic and scientific systematization an sich (in its own right), is supposed to be transmitting information without any explanatory texts. No pedagogical efforts were (are) made to integrate visitors in the discourse. The educated visitor is supposed to know what it all is about. Museums who define themselves as 'Enlightenment' institutions also show - even this day - an extraordinary lack of interest in the societies of which they are a part, perhaps with the exception of some Natural History Museums. Needless to say, most art exhibitions, especially the old national galleries, are still to be sorted into Episteme I.

One early example of how scientific thought, classification and theory of historical progress were "embodied" in a museum display was the Altes Museum, designed by Karl Friedrich Schinkel in Berlin, opened in 1827. The Altes Museum was constructed according to Hegel's chronological and progressive epochs. The entire museum, says Beat Wyss, could be interpreted as Hegel's philosophy turned into stone (Wyss ,1994). Simply 
through exposure to art and artefacts, the mind of the individual visitor would be improved; he was supposed to "learn" something just by looking. Another example of an Episteme I museum was the Thomsen's Museum in Copenhagen (1816), the predecessor of the Danish National Museum. This museum was organized chronologically in terms of progress, in the very modern epochs of Stone-, Bronze- and Iron Age. Thomsen's Museum became the prototype for all archaeological museums, as did the Altes Museum for the Art museums.

Yet another example would be the Museum of National Antiquities in Stockholm. At its (new) opening in 1943, the "expository agency" expressed the taxonomy and display principles of Episteme I. It still does, with the exception of the rather new archaeological exhibitions Prehistory I and Prehistory II - examined by Eva Insulander in her thesis (which would represent Empisteme I and Episteme III respectively (Insulander, 2010). In the newly constructed museum of 1943, each exhibition hall was designed in the appropriate architectural style of the epoch in question; so there was, and still is, a Roman hall, Medieval hall, Gothic hall and Baroque hall. Although the museum is called the Historical Museum in Swedish, very little history is told or seen or narrated. The items in the Medieval, Gothic and Baroque halls are treated as unique pieces of art displayed according to a purely aesthetic discourse, as in an art exhibition. The lack of explanatory texts in these sections is almost total.

The French Revolution marked a disruption not only in politics but also in the way scientific knowledge was organized. According to Foucault, by the beginning of the nineteenth century the 'classical epistème' turns into a 'modern epistème', which encompasses the idea of progress in history (Foucault, 1991). History entered the scene as a discipline with Man as focus of interest. Knowledge about things became equivalent with knowledge about the history of things (and their belonging to nations). Europe became obsessed with history and archaeology.

Specialized museums of archaeology, anthropology, cultural and natural history emerged during the first decades of the nineteenth century, organizing their exhibitions according not only to taxonomy, but also to chronology and progress, in a linear train of Time (as we saw in the example of the Altes Museum above). 
THE NATIONAL DISCOURSE AND THE INTRODUCTION OF TEXT

The most important shift of exhibition epistemes occurred with the introduction of political ideology, texts and pedagogical means in museums. This was the result of the political development in society after the French Revolution and the emergence of the Nation State (Weber 1976; Anderson 1983) Nevertheless, the implementation of these new ideas in museums was very slow. Although written text, context and pedagogy were introduced, it was not until the second half of the 19th century that they really became commonplace. Not until after World War I did more modern pedagogic ideas make their way into museums as servants of the nation. And the real breakthrough came only in the 1960's.

However, after the French Revolution the people was on the march. The introduction of the citizen into the mission of the museum can be observed already in Étienne-Louis Boullée's phantasmagoric plans for a Musaeion, dated 1783 (Fliedl \& Pazzini, 1996, p. 131-158.). The museum was intended to pay homage to a new political order. It was to be a place where the people would worship the greatest heroes of the new 'nation' and where citizens and their leaders would come together to express their collective political identity. This idea of national inclusiveness constitutes an important difference in relation to the museums of the classical Enlightenment and Episteme I. Boullée's Musaeion - never realized - was "a place to experience the sublime presence of a new public" (Wyss, 1994, p. 35). It anticipated nationalism and the education and indoctrination of the masses into this ideology. It also anticipated the idea of the museum as a means of integrating common people into the 'democratic' processes of ruling the nation state. Boullée's project indeed anticipated the opening of the Louvre for the people in 1793. Immediately after the Revolution, the Directory had realized that if common people were to understand anything of the contents of the museum, some elementary texts (labels) and explanations were needed.

Pure chronological and taxonomical exhibitions (Episteme I) were by many a critic considered too narrow and unsatifying as for the needs of the audience. This criticism went along with the development within historical research, where criticism was directed against a positivistic apporach. History was becoming fragmented "data" which prevented narrative historic reconstructuion (Klinge 2002). Museums displayed accurate scientific re- 
sults of research and documentation, but lacked, as we have seen, comprehensible context and historical reconstruction. The visitor lacked guidance, lacked means of associating, meaning-making, "learning" about life in the past. Already in 1819, Goethe was frustrated after visiting a museum which he considered incomprehensible for common people, and made an apology for the visitor and his needs: „Der Besucher ist das wesentliche Element des Museums! So waren die Museen ein Gesellschaftsproblem. /.../ Ohne Betrachter sind alle Kunstwerke wertlos!" Goethe's statement was also a very early remark on the new social and political duties of the Museum of Episteme II.

The museum of the 19th century was not only a political tool for the Nation State to promulgate nationalism, it was also a response to the ("foucaultian") time-problem of modern society. It was a kind of time-transformer which sought to fabricate and maintain History as collective experience and identity. For almost a couple of hundred years there has been a strong belief that museums could maintain and foster not only national identity but also the humanist universality of experience, based on the Humboldtian ideal of 'Bildung' (cultivation/erudition). Through a 'Bildungsprozess' (selfeducation/-cultivation) the individual was supposed to transgress to sociality and obtain universal values (Vieregg, 1999). The creating of the past was the business of the archaeologists and historians - and with them the museums. Ever since the beginning of the 19th century public museums have been heavily loaded with moral ideas and civilizing rituals (Duncan, 1995; Bennett, 2005). The museums of archaeology, history, ethnography and cultural history of Episteme II were (are) supposed to tell the big narrative of the past of the nation state. This was an authoritative voice, who said: Look! This is how it was! This is who we are and who our ancestors were!" - in order to integrate the citizens into the national discourse.

To make people understand the history of progress, an evolutionary narrative had to be introduced, stories had to be told, and concrete examples from "real life" had to be added. But from the day of Goethe's remark, it took one more century until the museums began to satisfy public demands to any greater extent. 
The German historian Jürgen Steen has described the introduction of texts in the so far textless German museums as the result of heavy political pressure after the First World War, during the 1920's. This was due to the process of democratization after the World War I and the falling apart of the Wilhelminian state (Steen, 1994, p. 49). The question of texts in the museums went along with the development of the democratic society and parliamentaranism. Museums became public complements to schools. The 'national story', enhanced by positivist research methods, was in one way or another to be told in museum exhibitions - reflected also in the buildings (!) which were growing bigger and bigger (Fehr, 1988). Most "modern" museum buildings in Europe were constructed between the two world wars as symbols of extreme national power and authority of knowledge. Tony Bennett has captured the core of it:

To identify with power, to see it as, if not directly theirs, then indirectly so, a force regulated and channelled by society's ruling groups but for the good of all: this was the rhetoric of power embodied in the exhibitionary complex - a power made manifest not in its ability to inflict pain but by its ability to organize and co-ordinate an order of things and to produce a place for the people in relation to that order.(Bennett, 2003, p. 89)

All along the 2oth century the ambition to increase comprehensibility and attraction of exhibitions, resulted in a continuous addition of multimodal elements: more texts, pictures, films, slide shows, computers, design elements, colours, lights, scenography, theatre, actors, and so on. This again, created perceptual problems for the visitor. Instead of helping visitors to acquire knowledge, to get the message, exhibitions were (are) often so "heavily loaded" with information and options for "experience" that they put people off completely. There are several reasons for this "museum fatigue", of which I will briefly examine one.

\section{A PROBLEM OF TEXT AND NARRATIVE}

The introduction of texts in exhibitions was no simple affair. At the beginning texts were gradually implemented in exhibitions without much reflection. The idea was that objects and texts would support one another. There was a sender and a reciever and the message would go through - one hoped. This simplistic and in many museums still prevalent approach, almost to- 
tally ignores the very complex communicative processes occurring between objects, texts, space, glass cases, exhibition designs and, finally, the visitor and his/her movements in an exhibition.

A text is a specific linguistic representation of reality and it has its own grammatical rules. An object, too, is a special kind of representation, as is an image, each with their own rules. When texts and images are attached to objects, this means loading the exhibition with very different representational modalities, whose epistemological points of departure do not necessarily coincide, as Mieke Bal has shown (Bal, 1996). I would designate this the 'problem of multiple representation'. The idea is, of course, that these different modes of representation would support each other in a narrative that progresses in a linear story through the exhibition space.

Texts and images are supposed to "illustrate" objects, and vice versa; objects "illustrate", or serves as material "evidence," for the text - allocate it authority as representing the "truth". But from another, communicational and semiotic point of view, different representations might 'disturb' each other. If the 'multiple representation' is scrutinized from a communicational point of view, the clash of different representative modes and ontologies is inevitable and easily splits up the attention of the visitor. The resources and flow of information, and modes of attraction can be overwhelming and make it difficult for a visitor to keep focus. Particularly difficult is - as those of us know who are frequent museum visitors - to keep up with a long (historic) narrative, the "textual red thread" of the story.

This multiplicity of resources, means and modes of communication in an exhibition (e.g. of cultural history) indeed makes the didactic aspects of an Episteme II exhibition very hard to master. As long as the texts designating the objects are of the simple documenting and explanatory "label" kind, it might work. But as soon as the ambition is to tell a real story, a "Big Narrative" such as the History of a nation or of whatever larger entity of facts, in a linear course, there will be a problem. To keep a narrative going, to keep it intact, from room to room loaded with gadgets, glass cases, masses of modalities, not to mention progressing from one floor of the building to the other, is, in my opinion, impossible. The narrative inevitably 'falls to pieces', usually already after the visitor has passed through the first room of the exposition. The multimodality of the medium itself so splits up the attention of the visitor that the Narrative more or less collapses. 
The exhibition makers and curators might try ever so hard to keep up the focus of the visitor, to make him/her "stay with them" along the narrative, the visitor will not "obey rules", (s)he often refuses to 'read' the exhibition as it is supposed to be read and refuses to go where (s)he should, or cuts the visit short and misses the main part of the story. Visitors have other and more important things to do than to keep the storyline intact in their mind. She lingers around, lets her associations flow, feels the atmosphere, dreams, talks to people, admires this or that detail, makes comparisons, relates to her own life and experience, and finally goes for a cup of coffee forgetting all about the exhibition.

The visitor 'experiments' conducted in the research project by Eva Insulander very much confirm my hypothesis of the problem of "multiple representation" in exhibitions. Particularly in Prehistory I, it is surprising how little the visitors 'remember' afterwards in their own representations of their visit - or of the structure and contents of the exhibition.

However, although the museum curators and pedagogues never actually have succeeded in forcing visitors to behave as they should, they have (till this day) never really given up their ambitions to try. Consequently, the ambition to narrate for instance "The History" of a nation in a museum is, in my opinion, a rather bad idea. But this persisting idea can be traced right back to the beginning of the 19th century when History (and archaeology) was adopted by the Nation State as a means of creating an imagined community and a collective identity.

Over the last two decades or so, along with the ICT- revolution and globalization, one can discern a growing awareness of this problem. This has had some deep impact on how exhibitions are planned and organized.

EPISTEME III: 'VISITOR's VAlue' AND THE FREEDOM OF CHOISE

To begin with, I presuppose that during the last decades a transition has occurred in the arts from Logical Empiricism to Hermeneutics. Life and world are now explained as culturally and socially constituted phenomena, dependent on the subjective view of the interpreter. In a world that demands all things to be made available to individual experience and demands, the museum - persisting with the paradigms of the 19th century nationalism and universally civilizing values - faces serious challenges.

By the end of the twentieth century, economic globalization and the 
decline of the concept of nation state had brought with it extra degrees of complexity. As a consequence of the decline of universalism, of the one and only "scientific truth", of collective measures of value, many museums have experienced a loss (or crisis) of identity. Science and technology have left the territorial Nation State behind and are actively pursuing global virtual networks and new "communities". What is left for the national museum(of history or cultural history and archaeology) when society has moved on? Will the classical museum survive the very historic (industrial) epoch that gave it birth, an epoch we (the West) have now left behind? Human sciences and museums follow - out into cyberspace, into the universe. In this situation we enter Episteme III - which might not be an "episteme" but perhaps rather a post structuralist 'Strategy' of exhibition organization.

\section{RADICAL INDIVIDUALIZATION AND VISITOR'S VALUE}

Today, museum and exhibition discourses have started to change. The shift is twofold; on the one hand a change of practices due to technological development and the breakthrough of ICT in the museal world: museums have entered 'cyber space' with radical consequences (Milekic, 1999). On the other hand it is a slow and somewhat delayed response to general shifts in Western society during the last 25 years or so. In politics it is a shift from pure national narrative to multiculturalism and globalization; in economy a shift from cooperation and classical liberalism to new liberalism and market economy (Hutton \& Giddens, 2000; Castells, 2004; Castells, 2000); in the scholarly field a shift from positivism to hermeneutics, from ontological values to phenomenological values (Gardner 2006) and finally a shift from the "age of production" to the "age of information and story telling" (Jensen, 1999)

Radical individualization is closely connected to the rejection of universal values, since if there are no 'objective truths' it is up to the individual to establish her own principles and standards. Instead of looking outward for a universal prototype, the individual looks inward and tries to build up his or her unique self:

In the individualized society the individual must/.../ learn to understand himself as the centre of events, as an 'administration office' for his own existence, talents, orientations etc. If one will survive, one must ignore intellectual games and develop a self-centred world view, which turns the relation- 
ship between the individual and society upside down, thinking it in a way which is usable for the individual's purpose (Beck 1986, 2000).

In the realm of pedagogy and learning the Danish social analysts Lars Geer Hammershøj and Lars-Henrik Schmidt have created theories of 'self-formation' and 'self-performance'. Self-formation is seen as opposed to the traditional concept of universal 'Bildung (cultivation)'. Self-formation is an aesthetic practice of the self, concerned with the unfolding of the personality. Whereas in the classical concept of Bildung, the individual (ideally) assimilates the universal values and becomes part of the larger, in the case of self-formation the individual experiences the larger, and then returns to his or her own particularity. Self-performance is, consequently, the way an individual seeks on a "social stage" to perform the personal qualities she has gained. (Hammershöj, 2003, p. 443-444; Houlberg Rung, 2007).

Museums have - to some extent - responded to the individualization and diversification of historical interpretation and to new theories of learning. They have also - certainly - adapted to the challenges of capitalism and market economy by modifying the concept of "stake holder's value" into "visitor's value" as a guiding principle of pedagogy and communication. In their approach to visitors, many museums have proceeded from supporting the concept of universal humanistic education/erudition to modern subjective "self-formation" and "self-performance". What lies behind all this is the market based community in which choice in the market is the ruling metaphor.

National narratives are being replaced or paralleled by a multiplicity of storytelling and multiculturalism. The consequences for museums would be a shift from Episteme II to Episteme III. Has he Foucaultian obsession with Time, History and Identity come to an end? Is history falling apart? The national rhetoric is in serious difficulties as differentiated knowledge is making its way with a multiplicity of narratives, stories, histories; local, regional, national, global. Are we witnessing a poly-vocal intrusion into the sacred museum space? Yes. People will choose their own history and identity and cultural belonging as they find appropriate. As an example of this culture of choice, one could mention the frequent use of audio-guides today. With a small computer borrowed from the reception, the visitor can build up his own collection of art. When finishing the tour he returns the 
guide and get his own "storyline" of art printed out in a catalogue.

Since the early 1990s, many museums have responded to the individualization of historical interpretation, indeed of knowledge and memory altogether, and to the victory of hermeneutics in the Arts (particularly in history and archaeology).

But is the dissolution of a "universal" common narrative a problem? Nonot if the museums take this into account and change their paradigms and exhibition practices in as far as it comes to access and dialogue - and accept a globalization and universalization of heritage, collections and objects.

In universities there is an ongoing and increasing trend of innovative cross-disciplinary cooperation and network building. Many museums follow the trend. There is today a new awareness - or actually an opinion - of the museum being a "meetingplace", a medium of communication and dialogue, between people, between cultures and subcultures. There is also an awareness of visitor's behaviour: instead of 'teaching' the visitor and telling her "how things are", as in Episteme II, museums offer a wider range of resources for the visitor to use if he wants. Visitors today are considered free individually to choose what "knowledge" and information they want and proceed in the exhibition as they wish. However, the museum remains as the site where a particular selection of things is put on display - as the environment in which experience and choice takes place. As in the supermarket, this is a choice only from what is offered.

Museums do indeed have to reformulate their traditional values and accept more openness, uncertainty and freedom of interpretation. Making an exhibition within Episteme III is also easily individualized: the curator is seen as an "auteur". In an exhibition of Episteme III, the meaning of things can no longer be fixed, nor collectively understood, as in Episteme II. A museum can only provide tools and resources for visitors to use as they find appropriate. Visitors create their own meanings. The museum will become a stage for action, a meeting place, a 'switchboard' for information and a showroom for a pluralistic reality. The museum world is, using Manuel Castell's words, forced to move on from a "space of location to a space of flows" (Castell 2004). Imagination and innovation are supported. The most intense production of 'knowledge' happens nowadays inside the 'flows' and through innovative, often cross-disciplinary connections. 
Moreover, the 'virtual world' has indeed questioned our relation to the material world and caused some irreversible rupture in the relations between Subject and Object, between Mind and Body (Lyotard, 2003, p. 165).

Consciously or not, Episteme III borrows structures and principles from the world-wide-web. Instead of trying to visualize or illustrate a narrative with the aid of texts and objects laid out linearly, the exhibition might be organized more like a net-work of 'knowledge stations' or information resources. This kind of exhibition could be designated a structuralistic or reflexive exhibition model. There is a mode of reception attuned to browsing. The visitor is allowed to go 'surfing' on the information network, not only among objects and contexts in the exhibition space, but on IT-stations and computers, virtual images and games. One is permitted to move in-and-out between the 'real' world and the virtual world, and the exhibition might be going on simultaneously in both. Museums of the future will invite the visitors to 'surf' into adventurous landscapes of knowledge. In its most developed form, ICT is here not only integrated but even inherent in the exhibition.

A 'reflexive' exhibition is characterized by visual and material pluralism and multimodality, and by a surprising juxtaposition of things. There would be a multidisciplinary approach and explanation and a pluralistic form. These new influences in exhibition making has been named a 'reflexive typology' (Hjorth Christensen, 1999, p. 29-45). Again, the exhibition structures reflect trends in science and philosophy: aren't these exhibitions reflections of phenomenology, (post)structuralism and information technologies - as those of the 18th and 19th century were reflexions of taxonomy and positivism!?

In the museum of Episteme III, the contemporary visitor could be resembled with 'path finder' sniffing and 'hunting' interesting quarries, or a modern collector gathering pieces of universal 'knowledge' according to their own interests and desires, afterwards to make their own decisions, conclusions and interpretations about the contents. Among resources, narratives and contexts provided, the visitor has but to choose. Visitor can also build their own exhibition - in their head, but also in making their own exhibition catalogue or their own exhibition on the web - by picking objects from the museum's digitized collections and putting them on display in an "empty room" where 'glass cases' are provided. For instance on the National 
Museum's of Denmark home page you can build your own exhibition, a contemporary Kunstkammer!

This mode of organizing exhibitions fits well into the new pedagogy of self-formation. Classical Taxonomy will be shifted to, or paralleled with, "Folksonomy", the wonderful term used e.g. by the San Francisco Museums of Fine Arts. Folksonomy refers to a user generated taxonomy, a digital search engine created by the visitors themselves, according to the fancy questions they ask and key words they put into the search functions of the museum. Thus new narratives of history and social development can be created, even beyond the control of the Nation State, or the museum itself.

Seemingly, we are eventually carrying out the wish of the French museologist Hugues de Varine (in the 1970's) that museums should be selective and "client-oriented. The situation has created a "connecting people" kind of experience which opens possibilities to collectively sharing information and resources with others, with people you choose yourself, locally, regionally, nationally or internationally. In my opinion we are witnessing new kinds of collectivism which, in my view, may, in a fascinating way, restore the creativity of memory, the unpredictability of History that was lost at the time af the introduction of national narratives, of "the one way things are".

To cope with the external "technological push" and "users' push", both demanding accumulation and aggregation of information on the WorldWide-Web, museums ask new questions and scrutinize their collections and means of interpretation and communication. Intensified research in collections, documentation, aggregation of information, references and "context building" in relation to objects will be of ever more importance in the future.

REFERENCES

Anderson, Benedict (1983). Imagined communities : reflections on the origin and spread of nationalism. London: Verso.

Bal, Mieke (1996). Double exposures. The subject of cultural analysis. London, New York: Routledge

Beck, Ulrich (1986). Risikogesellschaft. Auf dem Weg in eine andere Moderne. Frankfurt am Main: Suhrkamp Verlag.

Beck, Ulrich (2000). Living our own life in a runaway world. Individualisation, globalisation and politics. In Will Hutton \& Anthony Giddens (Eds.) Global Capitalism. New York: New Press. 
Bennett, Tony (2005). Civic laboratories. Museums, objecthood, and the governance of the social. Open University: Milton Keynes.

Bennett, Tony (2003). The exhibitionary complex. In Greenberg, Reesa, Ferguson, Bruce \& Nairne, Sandra (Eds.) Thinking about exhibitions. London: Routledge.

Castells, Manuel (2004), The network'society. A cross-cultural perspective. Cheltenham: Edward Elgar Publishing.

Castells, Manuel (2000). The information age: economy, society and culture. Vol. 3, End of millennium. Oxford: Blackwell.

Cousins, Julia (1993). The Pitt Rivers Museum. A souvenir guide to the collection. Oxford: The Pitt Rivers Museum.

Duncan, C. (2005). Civilizing rituals. London: Routledge.

Fehr, Michael (1988). Aufklärung oder Verklärung. In Jörn Rüsen, Wolfgang Ernst \& Heinrich Theodor Grütter (Eds.) Geschichte sehen. Beiträge zur Ästhetik historischer Museen. Pfaffenweiler: Centaurus-Verlagsgesellschaft.

Fliedl, Gottfried \& Pazzini Karl-Josef (1996). Museum - Opfer - Blick. Zu Etienne-Louis Boullées Museumsphantasie von 1783. In Gottfried Fliedl (Ed.) Die Erfindung des Museums. Anfänge der bürgerlichen Museumsidee in der Französischen Revolution. Wien: Museum zum Quadrat No 6.

Foucault, Michel (1991). The Order of Things. An Archaeology of the Human Sciences. London: Routledge.

Foucault, Michel (1980). Power/Knowledge. Selected interviews and other writings 1972-1977 [Ed. by Colin Gordon]. Brighton: Harvester Publ.

Gardner, Philip (2006). Hermeneutics, history and memory: interpretation and fact in academic research. London \& New York: Routledge.

Hammershøj, L.G. (2003). Selvdannelse og socialitet - forsøg på en socialanalytisk samtidsdiagnose. København: Danmarks Pedagogiska Universitet.

Heinisch, Severin (1988). Objekt und Struktur - Über die Ausstellung als einer Ort der Sprache. In Jörn Rüsen, Wolfgang Ernst \& Heinrich Theodor Grütter (Eds.) Geschichte sehen. Beiträge zur Ästhetik historischer Museen. Pfaffenweiler: Centaurus-Verlagsgesellschaft.

Hjorth Christensen, Line (1999). Den refleksive udstilling, belyst ved en museologi- og udstillingshistorisk tilgang. Kandidatafhandling, Moderne kultur og kulturformidling. Institut for litteraturvidenskab, Köbenhavns Universitet. November [unpublished MA thesis].

Houlberg Rung, Mette (2004). The National Art Museum as a Platform for Self-formation. Paper for conference Setting the Frames: Nations, Sciences and Professionals defining National Museums, 26-28 February 2007, Linköping University, Sweden.

von Humboldt, Wilhelm (1821). Über die Aufgabe des Geschichtsschreibers, Gesammelte Schriften Bd IV, 2. p 471.

von Humboldt, Wilhelm (1815-1834). Über das Museum, Gesammelte Schriften Bd XII, LIV-LVII. 
Hutton, Will \& Giddens, Anthony (2000)(Eds.). Global capitalism. New York: New Press.

Huxley, Robert (2003). Challenging the dogma. Classifying and describing the natural world. In Kim Sloan \& Andrew Burnett (Eds.) Enlightenment - Discovering the World in the Eighteenth Century. London: The British Museum Press.

Insulander, Eva (2010). Tinget, rummet, besökaren. Om meningsskapande på museum. Stockholms universitet. Institutionen för didaktik och pedagogiskt arbete.

Jensen, Rolf (1999). Dream society. How the C'coming shift from information to imagination will transform your business. New York: McGraw-Hill.

Karlsson, Ingemar (red.1997). Territoriets gränser. Stockholm. (Karlsson 1997:25).

Klinge, Matti (2002). Bokrådet och genius. In René Gothóni (Ed.) Att förstå inom humaniora. Finska Vetenskaps-Societeten. Helsingfors.

Kress, Gunther \& van Leeuwen, Theo (2001). Multimodal Discourse. The modes and media of contemporary communication. London: Routledge.

Lord, Beth (2004). Representing Enlightenment Space. Paper åresented at the conference Creative Space at Leicester University (Museum Studies) the 5-7th of April 2004.

Lyotard, Jean-Francois (2003). Les immateriaux. In Reesa Greenberg, Bruce C. Ferguson \& Sandy Nairne (Eds.) Thinking about Exhibitions. London \& New York: Routledge.

Milekic, Slavko (1999). Emerging tools \& techniques of digital media: history log and multiple futures. In D. Bearman \& J. Trant (Eds.) Cultural Heritage Informatics 1999: Selected Papers from ICHIM99. Archives \& Museum Informatics.

Muttenthaler, Roswitha \& Wonisch, Regina (2006). Gesten des Zeigens. Zur Repräsentation von Gender und Race in Ausstellungen. Bielefeld: Transcript Verlag.

Rasmussen, Anne (1992). Les classifications d'exposition universelle. In B. Schroeder-Gudehus \& A. Rasmussen (Eds.) Les fastes du progrès. Le guide des Expositions universelles 1851-1992. Paris.

Sloan, Kim (2003). Aimed at universality and belonging to the nation. The Enlightenment and the British Museum. In Kim Sloan \& Andrew Burnett (Eds.) Enlightenment - Discovering the World in the Eighteenth Century. London: The British Museum Press.

Steen, Jürgen (1994). Ausstellung und Text. In Wie zu Sehen ist. Essays zur Theorie des Ausstellens. Wien: Museum zum Quadrat No 5.

Turpeinen, Outi (2005). Merkityksellinen Museoesine. Kriittinen visuaalisuus kulttuurihistoriallisen museon näyttelysuunnittelussa. Helsinki: Taideteollisen Korkeakoulun julkaisu A 63.

Vieregg, Hildegard K. (1999). Wilhelm von Humboldts ideas on the education of human being: museologica, philosophical and educational contemplation. In Museology and Philosophy. International Council of Museums, ICOFOM STUDY SERIES - ISS 31. Coro, Venezuela. Nov. 28 Dec. 04. München: Museums-Pädagogisches Zentrum.

Wagner, Peter (1994). Fra kunstkammer til moderne museum. Nordisk Museologi 2. 
Weber, Eugen (1976). Peasants into Frenchmen. The modernization of rural France 1870-1914. Stanbford: Stanford University Press.

Wyss, Beat (1994). The Tübingen conspiracy. In: Nordisk Museologi 1. 
Editors

Susanne Kjällander, Stockholm University, Sweden Robert Ramberg, PhD, Stockholm University, Sweden Staffan Selander, Stockholm University, Sweden Anna Åkerfeldt, Stockholm University, Sweden Birgitte Holm Sørensen, Aalborg University, Denmark Thorkild Hanghøj, Aalborg University, Denmark Karin Levinsen, Aalborg University, Denmark Rikke Ørngreen, Aalborg University, Denmark

Editorial board

Eva Insulander, Mälardalen university, Sweden Fredrik Lindstrand, University of Gävle, Sweden Eva Svärdemo-Åberg, Stockholm university, Sweden

Copyrights No 1-2, 2012

Front cover: van Gogh Alive: The Exhibition. (c) Grande Exhibitions p. 2 Staffan Selander

p. 4 van Gogh Alive: The Exhibition. (C) Grande Exhibitions

p. 10 Staffan Selander

p. 14 Sophia Diamantopoulou

p. 19 Eva Insulander

p. 21 Fredrik Lindstrand

p. 23 Sophia Diamantopoulou

p. 24 Sophia Diamantopoulou

p. 36 Museum of National Antiquities

p. 41 Fredrik Lindstrand

p. 82 Flickr

p. 124 van Gogh Alive: The Exhibition.

(c) Grande Exhibitions

p. 125 Google's Art Project.

National Museum of Denmark. (C) Google p. 135 Vaike Fors
Advisory board

Bente Aamotsbakken, Tønsberg, Norway

Mikael Alexandersson, Gothenburg university, Sweden

Henrik Artman, KTH, Stockholm, Sweden

Anders Björkvall, Stockholm university, Sweden

Andrew Burn, London, Great Britain

Kirsten Drotner, Odense, Denmark

Love Ekenberg, Stockholm university, Sweden

Ola Erstad, Oslo, Norway

Chaechun Gim, Yeungnam University, South Korea

Erica Halverson UW/Madison, USA

Richard Halverson UW/Madison, USA

Ria Heilä-Ylikallio, Åbo Akademi University, Finland

Jana Holsanova, Lund University, Sweden

Glynda Hull, Berkeley, USA

Carey Jewitt, London, Great Britain

Anna-Lena Kempe, Stockholm university, Sweden

Susanne V Knudsen, Tønsberg, Norway

Gunther Kress, London, Great Britain

Per Ledin, Örebro university, Sweden

Theo van Leeuwen, Sydney, Australia

Teemu Leinonen, Aalto University, Finland

Jonas Linderoth, Gothenburg university, Sweden

Sten Ludvigsen, Oslo, Norway

Jonas Löwgren, Malmö University, Sweden

Åsa Mäkitalo, Gothenburg university, Sweden

Teresa C. Pargman, Stockholm University, Sweden

Palmyre Pierroux, Oslo, Norway

Klas Roth, Stockholm university, Sweden

Sven Sjöberg, Oslo, Norway

Kurt Squire, UW/Madison, USA

Constance Steinkuehler, UW/Madison, USA

Daniel Spikol, Malmö University, Sweden

Roger Säljö, Gothenburg university, Sweden

Elise Seip Tønnesen, Agder, Norway

Johan L. Tønnesson, Oslo, Norway

Barbara Wasson, Bergen, Norway

Tore West, Stockholm university, Sweden

Christoph Wulf, Berlin, Germany

ISSN 1654-7608

E-journal: ISSN 2001-7480

(C) The authors, 2012

(C) Designs for Learning, 2012

DidaktikDesign, Stockholm University,

Aalborg University 